\title{
A Comprehensive Force Majeure Model Clause in Corporate
} Transactions in Indonesia

\author{
I Gusti Agung Ayu Gita Pritayanti Dinar* and I Nyoman Putu Budiartha \\ Faculty of Law, Universitas Warmadewa, Denpasar, Bali-Indonesia \\ gitadinar@gmail.com* and budiarthaputu59@gmail.com
}

Published: 15/08/2020

How to cite: Dinar, I. G. A. A. G. P., \& Budiartha, I. N. P. 2020. A Comprehensive Force Majeure Model Clause in Corporate Transactions in Indonesia. Sociological Jurisprudence Journal. 3(2). 138-144. https://doi.org/10.22225/scj.3.2.1901.138-144

\begin{abstract}
Force majeure clause is presented in various models, from the simple to the complex ones that contain comprehensive descriptions, provisions, and notifications set out in an agreement with the details of the consequences of force majeure events. Force majeure clause serves as a complementary core clause and a renegotiating tool for the parties in the case of any event occurring beyond their reasonable control, which is important enough not to be overlooked by business actors. The Covid-19 pandemic which is currently ongoing worldwide, which has been declared as a global pandemic by World Health Organization (WHO) on 11 March 2020, has had a huge impact on the social life and the world economy which is very unsettling for business people, banks, and the society in general. The research questions investigated in this study are: (i) What are the factors causing failures in the performance of contractual obligations? (ii) What is a comprehensive force majeure model clause for corporate transactions in Indonesia? This study employs the normative legal research method. A normative legal research is guided by the characteristics of the object of the research, yet remains limited by the expected outcome of the norms initially established. The theories applied in investigating the problems in this research are the will theory (wilstheorie), trust theory (vertrouwensttheorie), and statement theory (verklaringstheori). In this study, will be identified a comprehensive force majeure clause enables the party who experiences a force majeure event to waive some provisions in the contract agreement.
\end{abstract}

Keywords: Comprehensive; force majeure clause; corporate transactions.

\section{INTRODUCTION}

Force majeure means an event/circumstance beyond the reasonable control of a party (VanHoeve, 1986), or overmacht, meaning uncontrollable force, uncontrollable event/circumstance, as set forth in Article 1245 of BW (Burgerlijk WetBoek), or things beyond one's power, uncontrollable causes, and together uncontrollable events/circumstances and fortuitous incidents are often considered as forming uncontrollable force (Termorshuizen, 1999). A force majeure clause is always positioned at the final part of the body of a corporate contract along with legal options and provisions on default and disputes in a corporate contract.

The concept of force majeure, though alien to common law, is an established doctrine in French law which relieves a promisor from responsibility for non-performance in certain circumstances (McKendrick, 1995). In other words, force majeure is a concept that allows a promisor non-performance of their obligations due to a force majeure event.

The International Chamber of Commerce's (ICC) Force Majeure Clause 2003 represented legal requirements of force majeure standards. This clause will follow if and to the extent that party proves a) that its failure to perform was caused by an impediment beyond its reasonable control; and $b$ ) that it could not reasonably have been expected to have taken the occurrence of the impediment into account at the time of the conclusion of the contract; and c) that it could not reasonably have avoided or overcome the effects of the impediment (The ICC Force Majeure Clause, 2003). The reasonable impediments determined by this clause are described in the next article, this Clause in case of the occurrence of one or more of the following impediments: (a) war (whether declared or not), armed conflict or the serious 
threat of same (including but not limited to hostile attack, blockade, military embargo), hostilities, invasion, act of a foreign enemy, extensive military mobilisation; (b) civil war, riot rebellion and revolution, military or usurped power, insurrection, civil commotion or disorder, mob violence, act of civil disobedience; (c) act of terrorism, sabotage or piracy; (d) act of authority whether lawful or unlawful, compliance with any law or governmental order, rule, regulation or direction, curfew restriction, expropriation, compulsory acquisition, seizure of works, requisition, nationalisation; (e) act of God, plague, epidemic, natural disaster such as but not limited to violent storm, cyclone, typhoon, hurricane, tornado, blizzard, earthquake, volcanic activity, landslide, tidal wave, tsunami, flood, damage or destruction by lightning, drought; (f) explosion, fire, destruction of machines, equipment, factories and of any kind of installation, prolonged break-down of transport, telecommunication or electric current; (g) general labour disturbance such as but not limited to boycott, strike and lock-out, go-slow, occupation of factories and premises (The ICC Force Majeure Clause, 2003). Paragraph 3 item (f) affirms that the impediment referred to in default is an epidemic. An epidemic is a contagious disease that spreads rapidly over a large area and causes many victims, for example a disease that does not permanently infect the area or an outbreak (Kamus Besar Bahasa Indonesia, 2016). Whereas what is happening right now all over the world is the Covid-19 pandemic, which is a plague that is simultaneously sweeping through humanity everywhere in the world, covering large geographical areas, continents or the whole world, a widespread epidemic disease (Kamus Besar Bahasa Indonesia, 2016). The Covid-19 pandemic emergency situation meets the criteria of a force majeure event as set forth in the provisions of The ICC Force Majeure Clause 2003.

A force majeure clause does not automatically relieve individuals not to carry out their contractual obligations due to an uncontrollable circumstance. Instead, one must make their best possible efforts and meet other provisions, and sometimes even present proof in the form of a government policy to show that a force majeure event has occurred. Therefore, an appropriate force majeure clause will be heavily relied upon to support these efforts.

\section{METHOD}

This research employs the normative legal research method, that is examining the law from an internal perspective with the object of research being a legal norm (Diantha, 2016). Legal research is a process to identify legal regulations, legal principles, and legal doctrines in order to address the legal issues at hand (Marzuki, 2005). Normative legal research functions to present legal arguments when there is void, obscurity, and conflicts of norms (Diantha, 2016).

The approaches used in this research are (i) the analytical and conceptual approach, through which all problems are investigated based on concepts, theories, principles, and the applicable laws and regulations, (ii) the statutory approach, which is applied in this study by examining, comparing, and analyzing the Presidential Decree Number 22 of 2020 on the declaration of the non-natural disaster of Coronavirus disease (Covid-19) outbreak as a national disaster (Presidential Decree No. 22 of 2020).

\section{RESULT AND DISCUSSION}

\section{Factors Causing Failures in The Performance of Contractual Obligations in Corporate Transactions di Indonesia}

The concept underlying a contract is a promise or an agreement whose administration and implementation can be enforced through the court, or which by the law is recognized as creating legal rights (Putra, 2017). The nature of a binding contract can be explained by several legal theories proposed by Roscoe Pound, namely: 1) Will Theory, 2) Agreement Theory, 3) Equality Theory, and 4) Loss Theory (Adolf, 2010). The Will Theory states that the parties wish to make an agreement and bind themselves by it, the agreement theory explains the existence of agreement as the basis for a creation of legal obligations, the equality theory states that equality has been established between the parties upon the contract in question, and finally the loss theory states that the basis for the creation of a contract is to impose liabilities on the other party with a loss as the outcome if the agreement is not implemented. The other party will be relieved from liabilities if they can prove that a force majeure event has occurred.

The drafting of a force majeure clause in relation to the pandemic that is currently happening in Indonesia will be better if it is supported by the theories and concepts that will underlie the drafting. A 
corporate contract, in the opinion of the authors, is in harmony with the theory of will and theory of agreement if the contract made by the parties reflects the earnestness of the parties' wills to set forth a comprehensive force majeure clause in a corporate contract.

The principle of contractual binding force (pacta sunt servanda) is the logical consequence of the effectiveness of the binding force of a contract (Hernoko, 2010). According to L. J. van Apeldoorn, there is a certain analogy between an agreement or contract and the law. To a certain extent, the parties entering a contract act as private legislators (Hernoko, 2010). This principle shows that a corporate contract that has been agreed upon by the parties is the law for each of the parties, and that every clause contained in the contract is binding upon the parties to implement. The same applies with a force majeure clause as well as other clauses contained in a corporate contract; they must be observed by the parties since the binding force exists as a result of a mutual agreement which is the will of the parties.

Essentially, a contract and an agreement are the same, as they bear the same concept of being a promise made by one or more individuals to do or not do something. However, there will be differences in the outcome of an agreement if during its implementation there is a problem that impedes it.

Default is generally defined as a failure in performing an agreement or non-fulfillment of a promise which is supposed to be delivered by the parties. Default is defined as the omission or failure to perform a legal contractual duty, esp., the failure to pay a debt when due (Garner, 2014). According to J. Satrio, default is a circumstance where a debtor fails to fulfill their promise or fails to fulfill it as they should, and such defaults can be blamed on the debtor (Satrio, 1999). Several important factors causing failures in the performance of contractual obligations are: a) Default, b) Overmacht, c) Hardship (Hernoko, 2010). These three factors are present in some model civil cases which usually occur in the implementation of a business agreement. Dispute, default, overmacht and hardship have different definitions and causes. Default is defined as the omission or failure to perform a legal contractual duty, esp., the failure to pay a debt when due (Garner, 2014). Hardship is an event that has fundamentally changed the contract's balance. This is caused by the costs of contract implementation increasing significantly or the value of contract implementation for the beneficiaries decreasing drastically, at that time (Article 6.2.2 of (Unidroit, 2016)). Force majeure means that the failure of a party to fulfill their obligations will be excused if the party can prove that the failure is caused by an impediment beyond their control and that it cannot be reasonably assumed that the party has calculated the impediment at the conclusion of a contract or to avoid or escape the consequences (Article 7.1.7 of (Unidroit, 2016)).

Default is regulated in Article 1238 of BW: The debtor is negligent if they, by a court order or by a similar instrument are declared negligent, or if according to their own legal obligations, it is stipulated that the debtor must be deemed negligent with the lapse of the prescribed time. A debtor is declared negligent if they (i) fail to perform their obligations; (ii) are late in performing their obligations; and (iii) perform their obligations but not in a manner that has been determined. Concerning default, Article 1243 of BW sets forth that payment of compensation, damages, and interest due to unfulfillment of a legal obligation will only be required if the debtor, after they are declared as being negligent in fulfilling their obligations, continue to neglect them, or if the thing that they have to provide or make can only be provided or made within the time period that has passed.

Default comprises the elements of failure, performance, and agreement, because default would not happen without an agreement between parties in the first place. Generally, default happens only when a declaration of negligence is issued (in mora stelling; ingebereke stelling) by the creditor to the debtor (Hernoko, 2010). Performance is the result achieved (from what has been performed, undertaken, etc.) (Kamus Besar Bahasa Indonesia, 2016). Default would only happen if the other party to the agreement promised to deliver some performance to the promisee. Default in Black's Law Dictionary is defined as "to be neglectful, to fail to perform a contractual obligation, to fail to appear or answer, to enter default judgment against (litigant) (Garner \& Black, 2009).

One example of the most common default in an agreement is default in a loan agreement. In general, this type of agreement contains provisions that govern matters of default as well as matters of disagreement or dispute in separate clauses, where it is further explained that in the event of default on the loan the debtor will be obligated to pay a penalty on the interest and the loan principal in accordance with what has been agreed upon as stated in the loan agreement. A definite period of time must be specified for the payment of the penalty and the interest so that the debtor knows and understand the 
sanction that they will be subject to if they violate the clause concerning the time limit for the payment in the loan agreement. Force majeure, according to Black's Law Dictionary, means an event or effect that can be neither anticipated nor controlled. The term includes both acts of nature (e.g. floods and hurricanes) and acts of people (e.g. riots, strikes and wars), and is also termed force majesture, vis major, superior force, act of God (Garner \& Black, 2009). Therefore, if in an agreement a force majeure clause is stated in detail, the parties will be able to calculate the worst possible risk that can happen.

The term force majeure, defined as an event or effect that can be neither anticipated nor controlled, includes acts of nature (e.g. floods and hurricanes) and acts of people (e.g. riots, strikes and wars), and is also referred to as force majesture, superior force, and act of God. Provisions on force majeure are set forth in Article 1244 and 1245 of BW on Payment of Compensation, Damages, and Interest.

There are several important factors that cause failure in the performance of contractual obligations, namely default, overmacht, and hardship. The definitions of overmacht (force majeure) and hardship are set forth in the 2016 UNIDROIT Principles (Principles of International Commercial Contract) (Hernoko, 2010). UNIDROIT is "an independent organization, free and unaffiliated. This organization was established with the purpose of "learning the needs and ways of modernizing and harmonizing the civil law, especially the commercial law existing both between states and between groups of states. Indonesia is one of the member states of the UNIDROIT (Putra, 2017). The important principles of force majeure or unforeseeable and uncontrollable circumstances are contained in Article 7.1.7 of the UNIDROIT Principles as follows:

Article 7.1.7

(Force majeure)

1. Non-performance by a party is excused if that party proves that the non-performance was due to an impediment beyond its control and that it could not reasonably be expected to have taken the impediment into account at the time of the conclusion of the contract or to have avoided or overcome it or its consequences.

2. When the impediment is only temporary, the excuse shall have effect for such period as is reasonable having regard to the effect of the impediment on the performance of the contract.

3. The party who fails to perform must give notice to the other party of the impediment and its effect on its ability to perform. If the notice is not received by the other party within a reasonable time after the party who fails to perform knew or ought to have known of the impediment, it is liable for damages resulting from such non-receipt.

4. Nothing in this Article prevents a party from exercising a right to terminate the contract

Based on the UNIDROIT principles, force majeure is recognized as one of the factors of performance failure of one or more parties to a corporate contract, which of course cannot be controlled, avoided, or intentionally created by either party to the agreement.

The pandemic which is still ongoing all over the world has hampered the economies of several countries, with the impact that many corporate transactions worldwide are delayed, halted, or even harmed due to the current pandemic. The President of the Republic of Indonesia Joko Widodo through Presidential Decree No. 12 of 2020 declares the non-natural disaster Covid-19 pandemic as a national disaster, a measure taken to accelerate the emergency management that must be implemented to mitigate the disaster's impact on the social and economic order of the country. The concept of this non-natural disaster being a force majeure event cannot automatically cancel all corporate contracts that are delayed by the pandemic. Instead, the event must be proven in court, and the declaration of a force majeure event can of course be used as a basis for a renegotiation for the party who fails to perform.

\section{Comprehensive Force Majeure Model Clause}

The central principles which have been recognised by the courts are that in order to constitute force majeure an event (to use neutral term) must have been (a) irresistible, (b) unforeseeable, (c) externality and must (d) have made performance impossible and not merely more onerous or difficult (McKendrick, 1995). The French court has determined several criteria that must be fulfilled by the party having the obligation to perform who is hindered from performing due to a condition called force majeure. Among 
these criteria is that the circumstance must be unforeseeable, not previously known to or influenced by the obliged party, and to perform the obligation is something that is not possible. The procedure for proving the fulfillment of some of these criteria must be strictly and earnestly observed and complied with by the party filing the application for release from obligations, because the efforts made by the party in question will be scrutinized by the court.

An event or effect that can be neither anticipated nor controlled, the term force majeure includes both acts of nature (e.g. floods and hurricanes) and acts of people (e.g. riots, strikes and wars), and is also termed force majesture, superior force, act of God. The provisions on force majeure are set forth in Article 1244 and Article 1245 of BW which govern Payment of Compensation, Damages, and Interest. Article 1244 of BW reads: If there is sufficient reason, the debtor must be sanctioned to pay compensation, damages, and interest if they are unable to prove that the non-performance or the untimely performance of the legal obligations has been caused by an unforeseeable event, and they cannot be held liable for all such matters if no ill will has been found in them. Article 1245 of BW reads: No damages or interest must be paid by the debtor if due to a force majeure circumstance or due to an accidental event they are prevented from providing or performing what they are obligated to, or if due to the same have committed a prohibited act. Both articles state the preconditions for force majeure or overmacht but do not describe in detail what constitutes force majeure events. However, the provisions in the 2003 ICC force majeure clause set them out in detail so that they can be used as a reference in drafting of a corporate contract.

The concept of force majeure originated in the Napoleonic Code. In common law, the concept evolved from one of physical impossibility to frustration of purpose (Augenblick \& Rousseau, 2012). Basically, a cooperation contract made by the parties have the aim to provide benefits for both parties, but in practice it is never fully known what will happen in the future, such as force majeure events. Sometimes a force majeure clause is made only as a complementary part of a contract, which eventually can cause chaos if the worst risk of an agreement is not prepared from the start. Therefore, it is important to have a clear, detailed and ideal clause concept in a corporate contract, which will give a sense of security and trust for the parties to the agreement.

Force majeure clauses are fairly standard in many legal contracts across industries (not just sports) but unless you're in an industry that is prone to be disrupted by natural disasters or other "acts of God," it normally would not stand any test. In contract negotiation people rarely consider such issues as the "Act of God" which may lead to severing the relationship (Kattah \& Welbeck, 2020). It is strongly recommended for business or industrial transactions to have a force majeure clause in their agreement especially in places that are prone to natural disasters, located in areas vulnerable to rebellion and war. Each corporate contract can be corrected from the start if the parties consider to include a comprehensive force majeure clause. If there is an unexpected event, a force majeure clause will enable the parties to do a reconstruction of the fulfillment of the contract. Such extreme events can include epidemics, pandemics, floods, famines, acts of war or terrorism, and changes in government regulations or laws that cause the agreement to be delayed or even canceled. This clause can also contain provisions which can be extreme from time to time by reducing the performance of an agreement.

A contract is an agreement between two or more persons which creates on obligation to do or not to do a particular thing (Garner, 2014). National contracts are distinguished from international contracts by the elements they contain. National contracts do not contain foreign elements while international contracts do. In general, the fundamental principles of international contracts consist of the basic principle of supremacy/sovereignty of national law, the basic principle of freedom of contract, the basic principle of the parties' autonomy, the principle of pacta sunt servanda, the principle of good faith, and the principle of reciprocity (Adolf, 2014). These principles form the basis of the formation of an agreement so that it must be prepared very carefully and with full consideration because it can have unexpected impacts in the future.

The birth of a contract is based on the will, a statement of mutual agreement on a contract, and the existence of trust between the parties. An agreement is binding because it is the will of the parties who want the agreement to be binding. In short, it is the parties themselves who state their will to bind themselves. This theory shows that a contract can only be made if there is a will and desire of the parties, but this theory has many objections to it because it is quite difficult to determine if a contract 
indeed is the desire of the parties who make it. The trust theory suggests that the statement which serves as the basis of a contractual obligation is a statement that should inspire trust that it is created in accordance with the decision of the will (Hernoko, 2010). These three theories will underlie the reasons for the birth of a corporate contract that contains a force majeure clause governing pandemics that the clause is a will expressed in a statement as a corporate contract built on a foundation of trust between the parties to the agreement.

A concept is a formation or formulation of a basic idea that is simpler into a design that is broader in scope and can be developed more deeply in the future. The meaning of the word concept is a design or idea or understanding abstracted from a concrete event (Kamus Besar Bahasa Indonesia, 2016). The concept of a clause in several law dictionaries and in the views of scholars is that a clause is a separate provision of an agreement, where one of the subject matters or articles are broadened or limited, and which broadens or limits, for example: the resulting agreement among the states contains a clause that governs assurance of freedom for small countries (Kamus Besar Bahasa Indonesia, 2016). The word clause in the Black's Law Dictionary is defined as a sentence or part of a sentence in a written instrument or statute (Garner, 2014). Force majeure clause is part of the corporate contract which is an inseparable and integral part of it unless it is agreed in the agreement to make amendments to this contract later on.

Several models of force majeure clauses are known, but as far as the authors' knowledge, they are rarely drafted in a comprehensive and detailed manner as to the information, conditions, and limitations to which obligations, so that sometimes doubts arise concerning the definition of and which events constitute force majeure in the agreement. The following is an example of a comprehensive force majeure model clause in a lease agreement:

(1) Force Majeure:

If any Party is prevented, hindered or delayed in its performance of any of its obligations pursuant to this Agreement by reason of Force Majeure, that Party shall be excused from the performance of its obligations during the existence of the Force Majeure and shall not be responsible for any damages suffered by the other Party as a result of its suspended performance, provided that the Party prevented from or delayed in performance, provided that the Party prevented from or delayed in performance by the Force Majeure shall use its best efforts to avoid and offset the effects of the Force Majeure.

The Party prevented from complying with its obligations pursuant to this Agreement by Force Majeure shall give notice to the other party of the circumstance preventing or delaying its performance and shall continue to take action to comply as fully as possible with its obligations under this agreement.

For the purpose of this clause, Force Majeure shall mean any event, the happening of, or the pernicious result of which, could not be prevented even though the person against whom it happened or threatened to happen were to take such appropriate care as might be expected from him in his situation; such as acts of God, acts of government, acts of war (declared or undeclared), hostilities, riots, civil commotion or unrest, military action, insurrection, fire, incendiaries, explosions, natural disasters, embargoes, future government restrictions, stoppage or delays caused by bureaucratic procedures imposed from time to time by government authorities, interruption of transportation due to Force Majeure events strikes, lockouts or other labour disputes and pandemic declared as force majeure by the government.

For the avoidance of doubt, the obligation to pay any amounts owed by any party under this agreement shall not be excused by force majeure.

This model clause, in the authors' view, is a very good effort to define a clear analytic framework and the specifications of events that must be included. However, the authors suggest some of the most important points, namely to identify and specifically mention all risks and re-review the clause in the context of a new contract in the future.

A comprehensive force majeure clause enables the party who experiences a force majeure event to waive some provisions in the contract agreement. However, such excuse is also not automatically granted by the other party, as the party that fails to perform must prove to be in good faith and not merely taking advantage of an unfavorable condition. 


\section{CONCLUSION}

Some important factors that cause failures in the performance of contractual obligations include default, overmacht, and hardship. Default is defined as the omission or failure to perform a legal contractual duty, esp. the failure to pay a debt when due. Hardship is an event that has fundamentally changed the balance of a contract due to something beyond the control of the parties such as an increase in the cost of contract implementation. Force majeure refers to a situation where failure to perform an obligation by a party is excused if the party can prove that the failure has been caused by an impediment beyond his control and that such an impediment could not reasonably be expected, and that the party could not have calculated the impediment at the conclusion of the contract or avoided or overcome it or its consequences. A specific and detailed force majeure model clause consists of all possibilities of force majeure and its regarded as being able to provide clear definitions to minimize and calculate the worst possible risks to encounter in the future, and provide a better course for renegotiation in the future as the force majeure clause has been agreed upon in advance by the parties in a corporate contract.

\section{REFERENCE}

Adolf, H. (2010). Dasar-Dasar Hukum Kontrak Internasional. Bandung: Refika Aditama.

Adolf, H. (2014). Dasar-Dasar, Prinsip \& Filosofi Arbitrase. Bandung: Keni Media.

Augenblick, M., \& Rousseau, A. B. (2012). Force Majeure in Tumultuous Times: Impracticability as the New Impossibility. The Journal of World Investment \& Trade, 13. Retrieved from https:// www.pillsburylaw.com/images/content/3/9/v2/3990/

BylinedArticleForceMajeureinTumultuousTimesJournalofWorldInvestm.pdf

Diantha, I. M. P. (2016). Metodologi Penulisan Hukum Normatif dalam Justifikasi Teori Hukum. Jakarta: Kencana Prenada Media Group. Retrieved from https://opac.perpusnas.go.id/DetailOpac.aspx?id=960380

Garner, B. A. (2014). Black's Law Dictionary, 10th Edition. West Publishing co. Retrieved from https:// books.google.co.id/books/about/Black_s_Law_Dictionary_10th_Edition.html? $\mathrm{id}=$ sKfIoQEACAAJ\&redir_esc=y

Garner, B. A., \& Black, H. C. (2009). Black's Law Dictionary. West Publishing co. Retrieved from https:// books.google.co.id/books/about/Black_s_Law_Dictionary.html?id=weU2AQAAIAAJ\&redir_esc=y

Hernoko, A. Y. (2010). Hukum Perjanjian A sas Proporsionalitas Dalam Kontrak Komersial. Jakarta: Kencana Prenada Media Group.

ICC Force Majeure Clause. (2003). ICC Force Majeure Clause 2003/ICC Hardship Clause 2003. Paris: International Chamber of Commerce. Retrieved from https:/iccwbo.org/content/uploads/sites/3/2017/02/ ICC-Force-Majeure-Hardship-Clause.pdf

National Education Department. (2016). Kamus Besar Bahasa Indonesia. Pusat Bahasa. Fourth Edition. Jakarta: Gramedia.

Kattah, J. K., \& Welbeck, B. A. (2020). The Corona Virus Pandemic and Its Impact on Economies and Employment. Academica. Retrieved from https://www.academia.edu/42784671/ THE_CORONAVIRUS_PANDEMIC_AND_ITS_IMPACT_ON_ECONOMIES_AND_EMPLOYMENT

Marzuki, P. M. (2005). Penulisan Hukum. Jakarta: Fajar Inter Pratama Offset.

McKendrick, E. (1995). Force Majeure and Frustration of Contract. United States of America: Informa Law from Routledge. Retrieved from https://www.abebooks.com/servlet/BookDetailsPL? bi $=12673637575 \&$ searchurl $=\&$ cmtrack_data $=$ cm_abecat\%3D100201986

Putra, I. B. W. (2017). Hukum Kontrak Internasional - The Law of International Contract. Bandung: Refika Aditama. Retrieved from http://disperpusip.jatimprov.go.id/inlis/opac/detail-opac/index?id=84290

Satrio, J. (1999). Hukum Perikatan Pada Umumnya. Bandung: Alumni.

Termorshuizen, M. (1999). Kamus Hukum Belanda Indonesia. Jakarta: Djambatan.

Unidroit. (2016). Unidroit Principles Of International Commercial Contracts. International Institute for the Unification of Private Law (UNIDROIT). Retrieved from https://www.unidroit.org/english/principles/ contracts/principles2016/principles2016-e.pdf

VanHoeve, W. (1986). Kamus Belanda-Indonesia. Jakarta: Ichtiar Baru. 